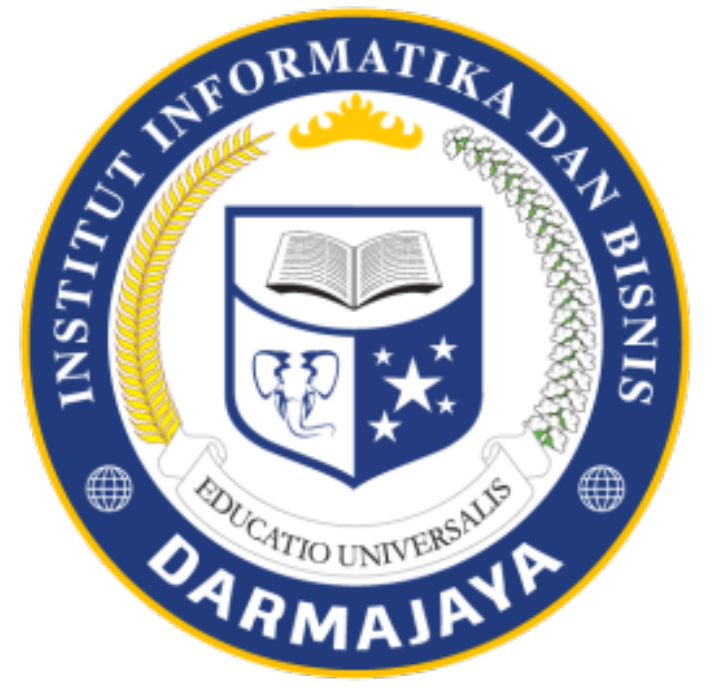

Dibuat oleh :

Andriyanto 1611050169

INSTITUT INFORMATIKA DAN BISNIS DARMAJAYA

BANDAR LAMPUNG 


\title{
Abstrak \\ Sistem Informasi Penyewaan Lapangan Futsal Pada Twins Futsal Segala Mider Bandar Lampung
}

Seiring dengan perkembangan zaman futsal mulai menjadi trend dari berbagai usia mulai dari anak-anak, remaja sampai orang tua. Selama ini pengelola lapangan futsal dalam melakukan pengelolaan data lapangan, data pelanggan, data jadwal, serta data penyewaan masih dicatat secara tulis tangan. Begitu juga dengan pelanggan, untuk memesan lapangan pelanggan selalu datang secara langsung ketempat lapangan untuk melakukan penyewaan, hal ini sangat membuang waktu. Teknologi informasi saat ini yang sangat digemari dan dimanfaatkan secara efektif oleh banyak orang adalah website. Dengan penerapan pemrograman web yang terintegrasi dengan sistem database, maka pengguna dapat melakukan pengelolaan. Pada tugas akhir ini dirancang Sistem Informasi Penyewaan Lapangan Futsal Pada Twins Futsal Segala Mider aplikasi berbasis web dengan menggunakan bahasa pemrograman PHP dan menggunakan Database MySQL. Aplikasi eFutsal ini dapat melakukan penyewaan lapangan futsal dan pelanggan dapat memesan lapangan futsal yang diinginkan.

Kata Kunci : Futsal, Web, Databases.

\begin{abstract}
Sistem Informasi Penyewaan Lapangan Futsal Pada Twins Futsal Segala Mider Bandar Lampung

Today futsal become a trend for people in various age, from child, young and old. All this time futsal field owner manage field's data, customer's data, schedule's data and also rent's data by manual. Customers also come by themselves to field rent to reserve the fields, this way waste the time. One of favorite information technology which use efective and efficiently is website. By apply website programming and system database integration, user will be able to manage data effective and efficienly. With the implementation of web programming that is integrated with a database system, the user can perform the management. In this final Sistem Informasi Penyewaan Lapangan Futsal Pada Twins Futsal Segala Mider designed webbased applications using the programming language PHP and uses a MySQL database. Applications can be e-Futsal indoor soccer field and perform leasing customers can order the desired indoor soccer field.
\end{abstract}

Keywords : $\quad$ Futsal,Web,Databases 
BAB I

Pendahuluan

\section{Latar beakang masalah}

Olah Raga yang banyak digemari oleh orang saat ini ,seperti olah raga futsal yang banyak diminati dan populer.seiring perkembangan zaman futsal menjadi trend dari berbagai usia mulai dari anakanak,remaja,bahkan orang dewasa sekalipun senang bermain futsal.futsal dimaikan oleh lima orang dalam satu tim ,tujuannya adalah memasukkan bola kegawang lawan dengan memanipulasi bola dengan kaki,selain lima pemain utama ,setiap regu juga dapat memiliki pemain cadangan .lapangan bola saat ini sudah sangat terbatas ,sehingga lapangan futsal menjadi alternatif dalam bermain sepak bola yang dimainkan diindoor maupun outdoordan ukuran lapangan futsal mempunyai panjang lebih kurang 25 sampai 43cm sementara lebar 15 sampai $25 \mathrm{~m}$ dengan ukuran yang kecil sangatmenghemat tempat, para pelaku bisnispun sangat tertarik dan berlomba-lomba untuk membuat lapangan futsal karena keuntungannya sangat besar dan mengiurkan untuk para pelaku bisnis.

Namun kebanyakan pengelola lapangan futsal dalam mengelola data lapangan,jadwal dan pemesanan ,serta data pelanggan masih dilakukan secara tulis tangan. Pencatatan jadwal penyewaanpun sering terjadi kesalahan karena informasi mengenai pemakaian kurang akurat .selain itu pembuatan laporan yang berhubungan dengan kegiatan penyewaan lapangan membutuhkan waktu yang lama dan belum maksimal karena masih dirancang dan disusun secara konvensional. Hal ini mengakibatkan pencarian data masih dilakukan dengan cara menelusuri arsip-arsip yang dapat menyita waktu yang cukup lama sehingga menurut saya kurang efektif
Sejalan dengan hal tersebut ,sesuai dengan kemajuan teknologi serta mengingat banyaknya minat untuk bermain futsal saat ini serta kurang baiknya dalam penyewaan lapangan futsal maka untuk meningkatkan kinerja pengelolaan lapangan dibuat suatu penelitian yang berjudul “ e-Futsal(Aplikasi Penyewaan Lapangan)

\section{Rumusan Masalah}

Bagaimana membuat aplikasi berbasiskan web untuk memberikan informaasi hasil penyewaan kepada pelanggan

\section{Batasan Masalah}

Batasan Masalah perancang aplikasi pemesanan lapangan futsal berbasis we antara lain:

1. Apliksai Tidak melakukan pembayaran secara online

2. Tidak menampilkan notifikasivia tranfer dengan syarat dan ketentuan

\section{Tujuan Penelitian}

Tujuan dari penelitian ini berdasarkan permasalahan yang telah dijelaskan diatas adalah sebagaiberikut :

1. Membuat aplikasi berbasiskan web untuk mempermudah admin master dalam mengelola data admin pengelola

2. Membuat aplikasi berbasiskan web untuk mempermudah admin pengelola dalam mengelola data lapangan ,jadwal dan data penyewaan

3. Membuat aplikasi berbasiskan web untuk mempermudah pelanggan dalam melakukan penyewaan lapangan

4. Membangun aplikasi yang dapat memberikan laporan data pelanggan ,data jadwal dan data penyewaan lapangan 


\section{Manfaat}

1. Bagi pelanggan,dari penelitian diharapkan dapat mempermudah dalam penyewaan lapangan

2. Menyajikan informasi kepada pengunjung tentang jadwal lapangan futsal

3. Mempermudah admin dalam mengelola data lapangan,jadwal dan data penyewaan

\section{BAB II}

\section{LANDASAN TEORI}

\section{Tinjauan Pustaka}

Aplikasi penyewaan yang akan dirancang mengacu pada tugas akhir yang sudah ada yaitu "Perancangan Sistem Informasi Penyewaan Lapangan Futsal Meteor berbasis Web” oleh sayogi(2013). Tema yang diangakt dari sistem tersebut tentang penyewaan lapangan ,pembuatan web ini lebih dikhususkan menggunakan satu tempat lapangan futsal dan menggunakan admin masih satu admin pada web tersebut . Berdasarkan referensi diatas penulis membuat sebuah web yang berjudul "e-Futsal (Aplikasi penyewaan lapangan)" selain memberikan informasi penyewaan lapangan futsal ,web ini juga dapat membuat banyak account admin sebagai pengelola dan memberikan fasilitas yang dimiliki untuk tempat lapangan

\section{Pengertian futsal}

Futsal adalah permainan bola yang dimainkan oleh dua tim yang masing-masing beranggotakan lima orang.tujuannya adalah memasukkan bola kegawang lawan dengan memanipulasi bola dengan kaki. Selain lima pemain utama, setiap regu juga diijinkan memiliki pemain cadangan.tidak seperti permainan sepak bola dalam ruangan lainnya ,lapangan futsal dibatasi garis bukan net ataupun yang lainnya dan sampai sekarang futsal masih banyak digemari oleh masyarakat dan banyak kompetisi yang diadakan khusunya di bandar lampung.

\section{Pengertian Penyewaan}

Sewa menyewa adalah suatu perjanjian atau suatu kesepakatan dimana penyewa harus membayar atau memberikan imbalan dan manfaat kepada dari benda atau barang yang dimilki oleh pemilik barangyang dipinjamkan. Hukum sewa menyewa adalah mubah atau diperbolehkan.contoh sewa menyewa dalam kehidupan ita sehari-hari misalkan kontrak mengontrak gedungkantor,kontrak rumah,sewa lahan tanah untuk pertanian, sewa/carter kendaraan, sewa lapangan futsal dan lain-lain oleh bahtiar (2011).

Dalam sewa menyewa harus ada barang yang disewakan,pemberi sewa,imbalan dan kesepakatan antara pemilik dan orang yang menyewa barang. Penyewa dalam mengembalikan barang atau aset yang disewa mengembalikan barang secara utuh seperti pertama kali tanpa kurang atau bertambah kecuali ada kesepakatanlain yang disepakati saat sebelum barang berpindah tangan.

a. Beberapa hal yang membuat sewa menyewa batal

1. Barang yang disewa rusak

2. Periode /masa pinjam/kontrak sewa menyewa sudah habis

3. Barang yang disewakan cacat setelah berada ditangan penyewa

b. Manfaat sewa menyewa

1. Membantu orang lain yang tidak sanggup memberi barang

2. Pemberi sewa medapatkan manfaat dari penyewa

Faktor-faktor yang mempengaruhi penyewaan antara lain:

1. Kondisi dan kemampuan penyewaan 

a. Kondisi lapangan yang disewakan
b. Harga sewa
c. Syarat penyewaan,seperti kartu keluarga,kartu penduduk

2. Besarnya modal usaha yang dibutuhkan untuk pembuatan lapangan futsal

3. Bagaimana manajemen usaha lapangan futsal yang baik

\section{Pengertian Web}

Web adalah sebuah kumpulan halaman yang menempilkan informasi data teks,data gambar diam atau bergerak,data animasi ,suara vidio dan atau gabungan dari semuanya ,baik yang bersifat statik mauu dinamis yang membentuk suatu rangkaian bangunan yang saling terkait dimana masing-masing dihubungkan dengan jaringanjaringan halaman(hyperlink). Halaman online yang memilki topik saling terkait terkadang disertai pula berkas-berkas gambar,vidio,atau jenis-jenis berkas lainnya. Sebuah website biasanya ditempatkan pada sebuah server web yang dapat diakses melalui jaringan seperti internet ataupun jaringan wilayah lokal(LAN) melalui alamat internet yang dikenali dengan URL. Website sendiri merupakan berkas yang dibentuk dengan intruksi-intruksi berbasis html,xhtml,atau bahasa scrip lainnya yang kemudian diterjemahkan oleh browser untuk menampilkan hasilnya,website dibagi menjadi dua jenis yaitu website statis dan website dinamis .website statis merupakan website yang memilki isi yang tidak dimaksudkan untuk diperbarui secara berkala sehingga pengaturan atau pemukhtahiran isi web tersebut dilakukan secara manual. Untuk membuat website statis tidak perlu mengerti secara mendalam bahasa html atau script lainnya karena website statis bahasanya akan dibangun oleh editor-editor yang dapat membuat halaman web secara otomatis. Website dinamis merupakan website yang secara spesifik agar isi yang terdapat dalam situs tersebut dapat diperbarui secara berkala dengan mudah.

Cara kerja web

Adapun cara kerja web adalah sebagai berikut:

1. Informasi web disimpan dalam dokumen dalam bentuk halaman-halaman dokumen atau webpage

2. Halaman web tersebut disimpan dalam komputerserver web

3. Sementara dipihak pemakai ada komputer yang bertindak sebagai komputer client dimana ditempatkan program untuk membuka halaman web yang ada diserver web(browser) browser membaca halaman web yang ada diserver web

Fungsi web

Secara umum situs web yang ada diserver web

1. Fungsi komunikasi

Situs web mempunyai fungsi komunikasi pad aumumnya adalah situs web dinamis .karena dibuat menggunakan pemrograman web (server side) maka dilengkapi fasilitas yang memberikan fungsi-fungsi komunikasi seperti web mail ,form contact,chatting form dan yang lainnya .

2. Fungsi informasi

Situs web yang memilki fungsi informasi pada umumnya menekankan pad akualitas pada kontennya karena fungsi situs tersebut adalah menyampaikan isinya ,situs ini sebaiknya berisi baris dan grafikyang dapat di download dengan cepat.pembahasan penggunaan animasi ,gambar dan elemen seperti java yang diyakini sebagai langkah yang dapat diganti dengan fasilitas yang memberikan fungsi informasi 
seperti,profile company,referency dan lain-lain.

3. Fungsi entertainment

Situs web juga memilki funsi entertaiment/hiburan bila situs web kita berfungsi sebagai saran hiburan maka penggunaan animasi ,ganbar dan elemen bergerak dapat meningkatkan mutu presentasi desainnya meski harus tetap mempertimbangkan kecepatan downloadnya

4. Fungsi transaksi

Situs web dapat dijadikan sarana transaksi bisnis baik barang,jasa atau yang lainnya. Situs web ini menghubungkan perusahaan ,konsumen dan komunitas tertentu melalui transaksi elektronik pembayaran bisa menggunakan kartu kredit ,tranfer atau dengan membayar secara langsung.

\section{Bahasa Pemrograman}

Bahasa pemrograman atau sering diistilahkan juga dengan bahasa komputer adalah teknik,komando,instruksi standar untuk memerintah komputer. Bahasa ini memungkinkan seorang programmer dapat menentukan secara persis data mana yang akan diolah oleh komputer ,bagaimana data ini akan disimpan/diteruskan,dan jenis langkah apa secara persis yang akan diambil dalam berbagai situasi.

Dalam konteks pemrograman,terdapat sejumlah terdapat sejumlah bahasa pemrograman seperti pascal,c++,dan basic.secara garis besar ,bahasa-bahasa pemrograman dikelompokkan menjadi dua yaitu

1. Bahasa beraras tinggi (hight-level language)

2. Bahasa beraras-rendah (low-level language)
Bahasa beraras tinggi adalah bahasa pemrogrman berorientasi kepada manusia.program dibuat menggunakan bahasa pemrograman yang mudah dipahami oleh manusia ,biasanya menggunakan kata-kata bahasa inggris misalnya IF untuk menyatakan "jika" dan AND untuk menyatakan "dan" termasuk dalam kelompok bahasa ini antara lainnya c++,pascal,basic dan lainnya.

Bahasa beraras rendah adalah bahasa pemrograman yang berorientasi kepada mesin.bahasa ini menggunakan kode binner (yang hanya mengenal kode 0 dan 1) atau suatu kode sederhana untuk menggantikan kode-kode tertentu dalam system binner.

Definisi MySQL

MySQL((Struktured Query Language) adalah bahasa yang digunakan untuk mengakses basis data yang tergolong relational .sesungguhnya SQL tidak terbatas hanya untuk mengambil data (Query),tetapi juga dapat dipakai untuk menciptakan tabel(CREATE),menghapus tabel(DELETE) menambah data kedatabase (INSERT) menghapus data di tabel (DROP),mengganti data tabel (UPDATE),dan berbagai operasi yang lain Abdul Kadil (2014:242)

\section{BAB III}

\section{METODE PENELITIAN}

Metode penelitian yang digunakan dalam penelitian menggunakan metode pengumpulan data

Tahap penelitian

a. Perencanaan

Dalam tahap ini akan direncanakan untuk tahapan-tahapan berikutnya agar nantinya bisa dihasilkan sebuah sistem yang baik.

b. Analisis sistem

Pada tahap ini dimana dilakukan pengumpulan data dari lapangan yang kemudian nantinya akan dianalisa untuk 
mendapatkan informasi yang akan

digunakan untuk mendesain sistem

c. Perancangan sistem

Pada tahap ini features dan operasi-

operasi pada sistem di deskripsikan

secara detail

d. Implementasi

Yaitu mengimplementasikan rancangan

dari tahap-tahap sebelumnya.

\section{Daftar Pustaka}

- Perancangan sistem informasi penyewaan lapangan futsal Meteor berbasis web” oleh sayogi (2013)

- Arief M Rudianto. 2011. Pemrograman Web Dinamis menggunakan PHP dan MySQL. C.V ANDI OFFSET. Yogyakarta.

- Konsep dasar PHP Abdul Kadir (2014:334)

- Definisi MySQLAbdul Kadir (2014:242)

- Sewa lapangan dan lain-lain Bahtiar(2011) 